Article

\title{
High-Density LiDAR Mapping of the Ancient City of Mayapán ${ }^{\dagger}$
}

\author{
Timothy Hare $^{1, *}$, Marilyn Masson ${ }^{2, *}$ and Bradley Russell ${ }^{3,+}$
}

1 School of Public Affairs, Morehead State University, Combs Building, Morehead, KY 40351, USA

2 Department of Anthropology, University at Albany-SUNY, Arts \& Sciences Building, Albany, NY 12222, USA; E-Mail: mmasson@albany.edu

3 Department of Math and Sciences, The College of St. Rose, Albany, NY 12203, USA;

E-Mail: bradley_russell@hotmail.com

$\dagger$ Based on a presentation presented at the 79th Annual Meeting of the Society for American Archaeology, Austin, TX, USA.

* These authors contributed equally to this work.

* Author to whom correspondence should be addressed; E-Mail: t.hare@morehead-st.edu; Tel.: +1-606-783-9436; Fax: +1-606-783-5092.

Received: 23 July 2014; in revised form: 8 September 2014 / Accepted: 9 September 2014 / Published: 23 September 2014

\begin{abstract}
A 2013 survey of a 40 square kilometer area surrounding Mayapán, Yucatan, Mexico used high-density LiDAR data to map prehispanic architecture and related natural features. Most of the area is covered by low canopy dense forest vegetation over karstic hilly terrain that impedes full coverage archaeological survey. We used LiDAR at 40 laser points per square meter to generate a bare earth digital elevation model (DEM). Results were evaluated with comparisons to previously mapped areas and with traditional archaeological survey methods for 38 settlement clusters outside of the city wall. Ground checking employed full coverage survey of selected $500 \mathrm{~m}$ grid squares, as well as documentation of the chronology and detail of new public and domestic settlement features and cenotes. Results identify the full extent of continued, contemporary Postclassic settlement (A.D. 1150-1450) outside of the city wall to at least 500 meters to the east, north, and west. New data also reveal an extensive modified landscape of terraformed residential hills, rejolladas, and dense settlement dating from Preclassic through Classic Periods. The LiDAR data also allow for the identification of rooms, benches, and stone property walls and lanes within the city.
\end{abstract}


Keywords: light detection and ranging (LiDAR); archaeology; Mesoamerica; bare earth; digital elevation models (DEMs)

\section{Introduction}

The goal of Mayapán LiDAR Mapping project is to contribute to long-term investigations at the ancient city by documenting the regional system of settlement and the environment in which it developed. Our research is framed within a political economy approach that seeks to identify and reconstruct dimensions of complexity and integration that link people together in the context of the environment. For instance, we ask the questions; how did household producers interact with governing elites? How were urban and rural communities interrelated? How did all community members subsist in this region? Hence we are constructing a regional database from which to study the processes of settlement growth, resource use, production activities, political organization, and sustenance of the largest Maya political capital of the Postclassic Period (A.D. 1150-1450).

The initial step in achieving this purpose is the construction of a comprehensive map of a $40 \mathrm{~km}^{2}$ area centered on the walled city of Mayapán using LiDAR-generated data, ground survey, surface collection, test excavations, artifact analysis, and GIS-aided spatial analysis. The analyses of these data allow us for the first time to fully map the urban structure of the city itself and characterize the regional social and environmental context in which the city was embedded. As analyses continues, we will explore the extent to which the urban and rural residential zone work forces were articulated with hierarchical authorities through formal spatial association with administrative features. In so doing, our results are contributing to the creation of a growing body of comparative literature on the complex patterns of households and administrative economies observed in ancient cities.

\section{Background}

\subsection{The Site and Its Setting}

The archaeological site of Mayapán is located $40 \mathrm{~km}$ southeast of the modern city of Mérida (Figure 1). Today much of the monumental center is restored and open to the public due to work of Carlos Peraza's INAH-Yucatán Project. Ejido cooperatives or individual landowners own other areas of the site. The entire area is distinctly flat in character and lies just above sea level. Soils are very thin, rarely measuring more than $40 \mathrm{~cm}$ deep. Exposed limestone bedrock is just as common as soil. The level surface of the land is broken up by numerous scattered low hillocks, typically only a few meters tall. Placement of structures on top of them was common [1,2]. The majority of the soil that does exist tends to wash down into low swales between hillocks. Placement of structures in these swales is typical of areas with documented agricultural production [3]. There is rapid drainage of seasonal rainfall into the karst limestone underground. Mayapán's location was probably determined in part by the density of water bearing cenotes in the area [1,2] as it is near a "ring of cenotes" around the brim of the Chicxulub crater [4], a zone that has a large number of archaeological sites [5]. 
Figure 1. The location of Mayapán in Mesoamerica.

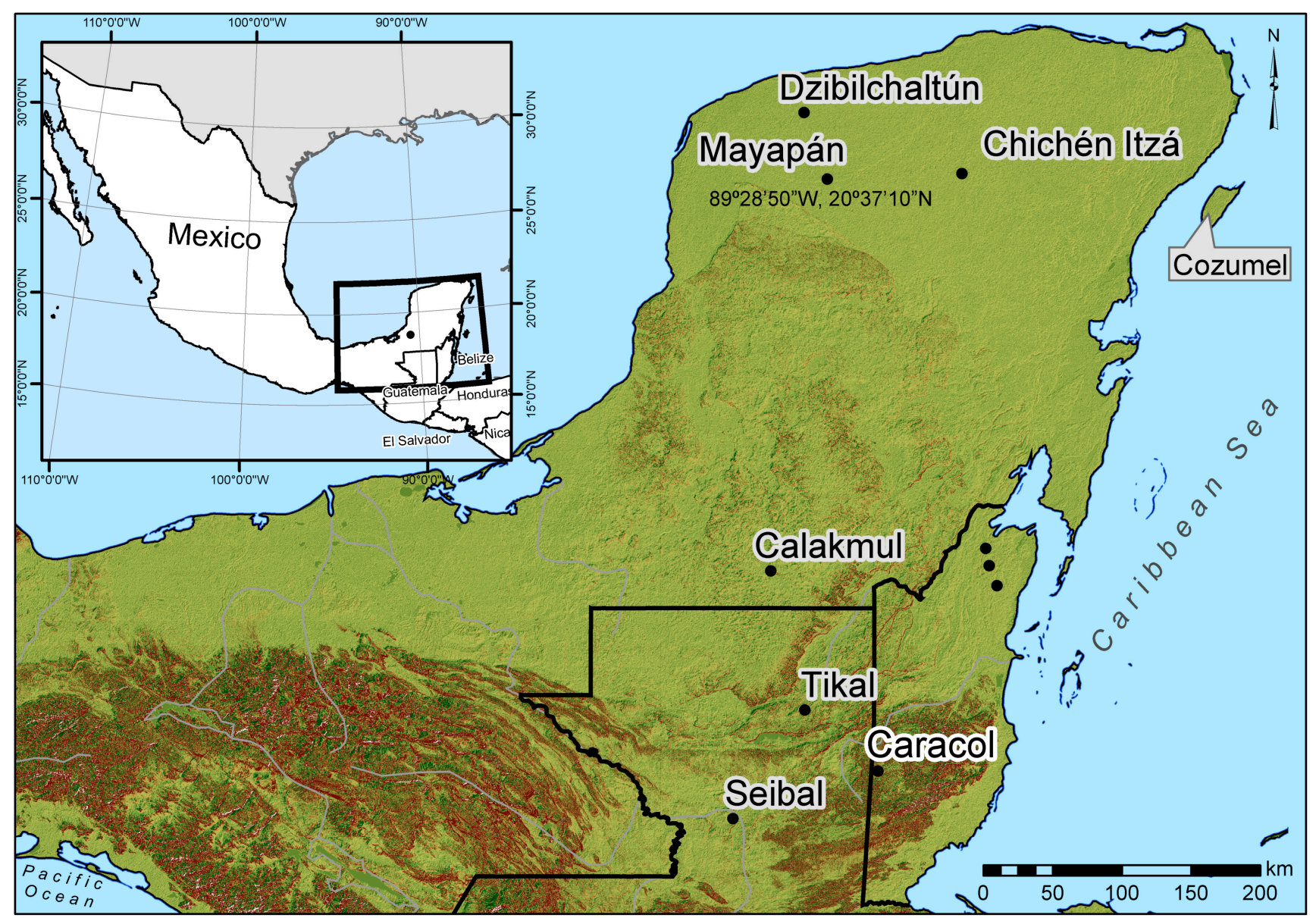

\subsection{Previous Investigations}

The comprehensive archaeological study of Mayapán began in 1948 with the arrival of a team of researchers from the Carnegie Institution [6-8]. Figure 2 shows major archaeological features of the city mapped by the Carnegie project. The city's defensive wall is in black and other ancient architectural features, such as houses, platforms, and walls, are in red. This team focused on a one hundred percent survey of the $4.2 \mathrm{~km}^{2}$ walled portion of the site contained within the $9.1 \mathrm{~km}$ circumferential wall that surrounds the majority of the settlement [9]. The Carnegie map recorded approximately 4100 buildings within or adjacent to the enclosure-just over half were thought to be residences [1]. Residential groups were defined by boundary walls that were only mapped for a small portion of the walled center [10-12] and A.L. Smith [1]. This unusual characteristic for a Maya city is observed at some other northern Maya sites like Chunchucmil [13], Dzibilchaltun [14], and Coba [15]. Groups of domestic structures in rural areas that specialize in agricultural production lack these formal walls [16]. 
Figure 2. Carnegie mapped features in the context of the regional survey. The city wall is black and general architectural features are red.

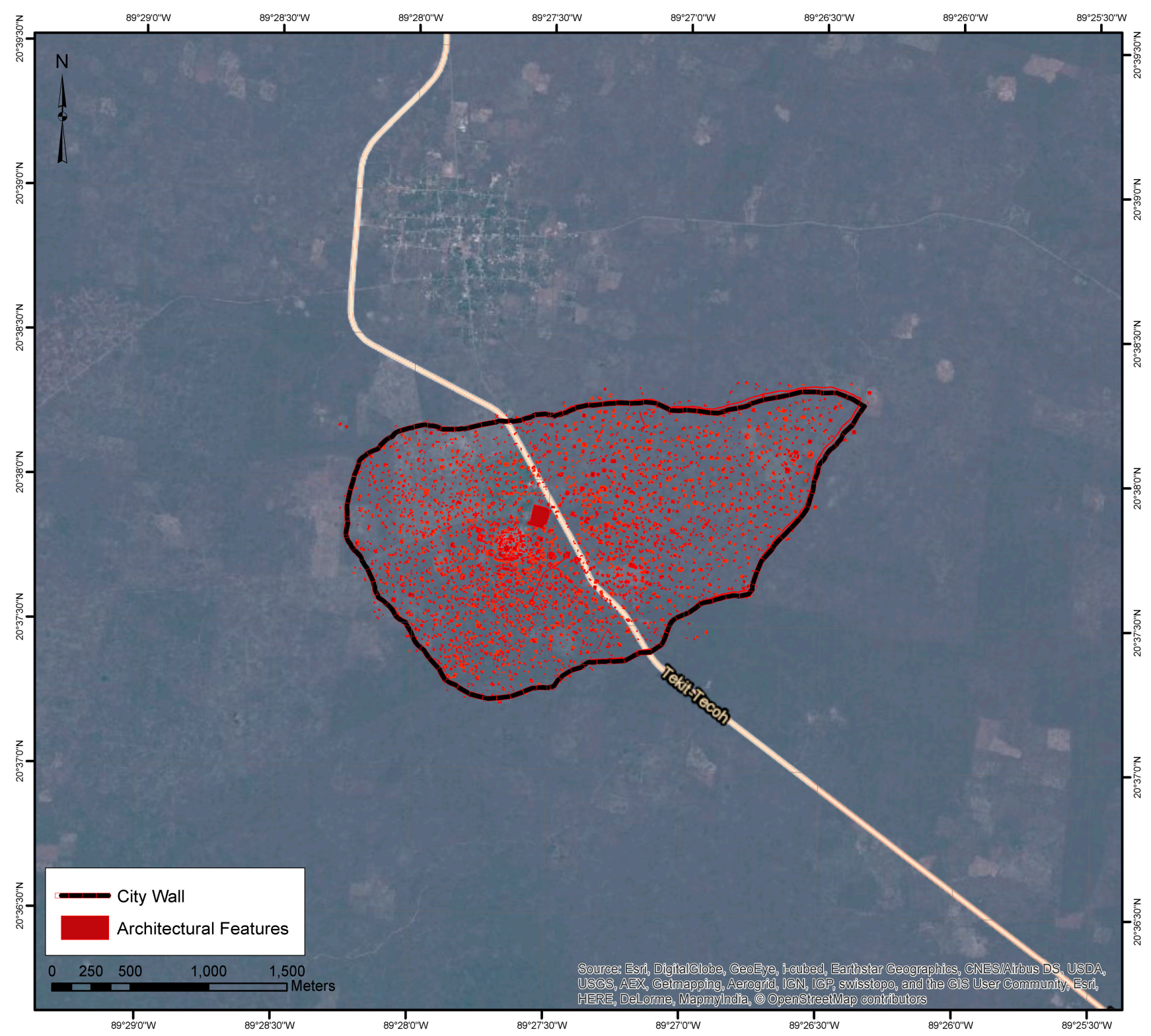

Carlos Peraza's INAH-Mayapán Project excavated and restored buildings of the city's primary monumental plazas in Square Q [16-18] (Figure 3). Brown [2] followed up A.L. Smith's [1] research with a series of excavations in the residential areas.

The Proyecto Económico de Mayapán Project (PEMY) accomplished intensive mapping, surface survey, surface collection, test-pitting program, or horizontal excavations in 36 sample areas of the city during 2002-2009 [19,20] (Figure 4). Results of the work were used to examine the spatial patterning of features such as lanes, plazas, administrative halls and residences. Analysis of $100 \%$ of the artifacts and faunal remains suggests considerable economic specialization at houselots across the city and the importance of the city's market economy. Twenty-eight household craft workshops are identified. Most of the city's households tended toward occupational specialization (craft and service professions) and were highly dependent on one another for the goods essential to daily life. The residents also 
depended on raw materials from distant towns and regions for textile, lithic, and shell production; raw goods were converted into valuables at the political capital.

Figure 3. Photo of Mayapán's reconstructed monumental plaza.

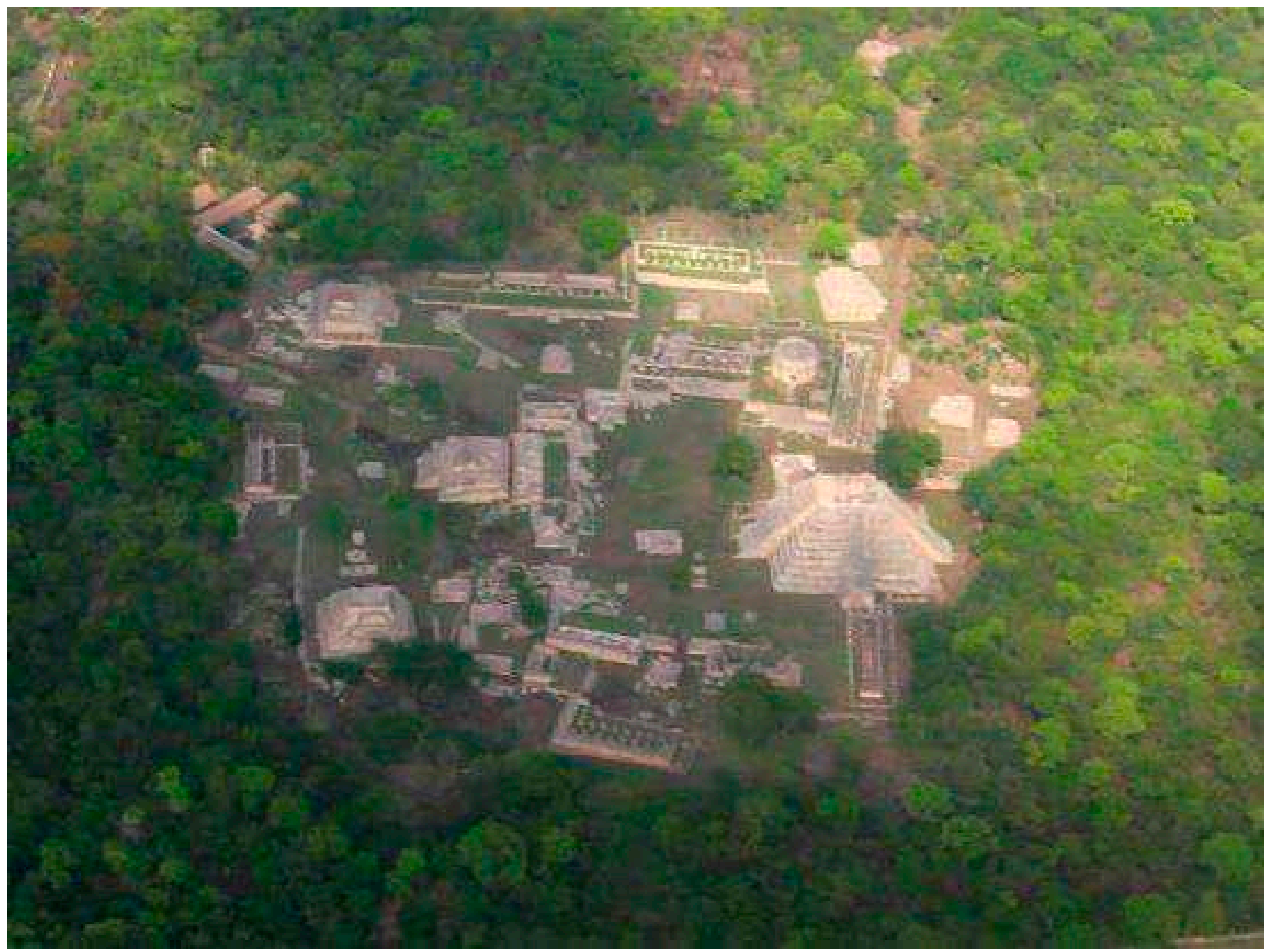

PEMY activities also include Brad Russell's [16] doctoral research outside of the city wall (Figure 4). He mapped all features in eight $250 \times 1000 \mathrm{~m}$ transects radiating out from the wall. Estimates of the residential portion of the site grew from the Carnegie's $4.2 \mathrm{~km}^{2}$ to between 8.8 and $10.1 \mathrm{~km}^{2}$. Beyond the occupied area, land use patterns reflect Mayapán's productive activities on the broader rural landscape. Settlement features and specialized resource extraction areas identified include: elite and commoner dwellings, ritual shrines and a colonnaded hall, cenotes, animal pens, lime plaster production features, granaries, apiaries, and field or terrace wall lines [16,21,22]. In total, this survey recorded 347 structures in 173 distinct clusters; a sample of these clusters was tested to establish chronology and function. These areas provide a starting point for understanding diversity in settlement features across Mayapán. Initial survey outside of the wall documented an $18 \%$ sample of the area within $1 \mathrm{~km}$ of the wall. This research suggests that the city is more than twice as large as has been accepted since the early work by the Carnegie project and increased the site's population estimate by more than $40 \%$. 
Figure 4. Proyecto Económico de Mayapán Project (PEMY) mapped areas.

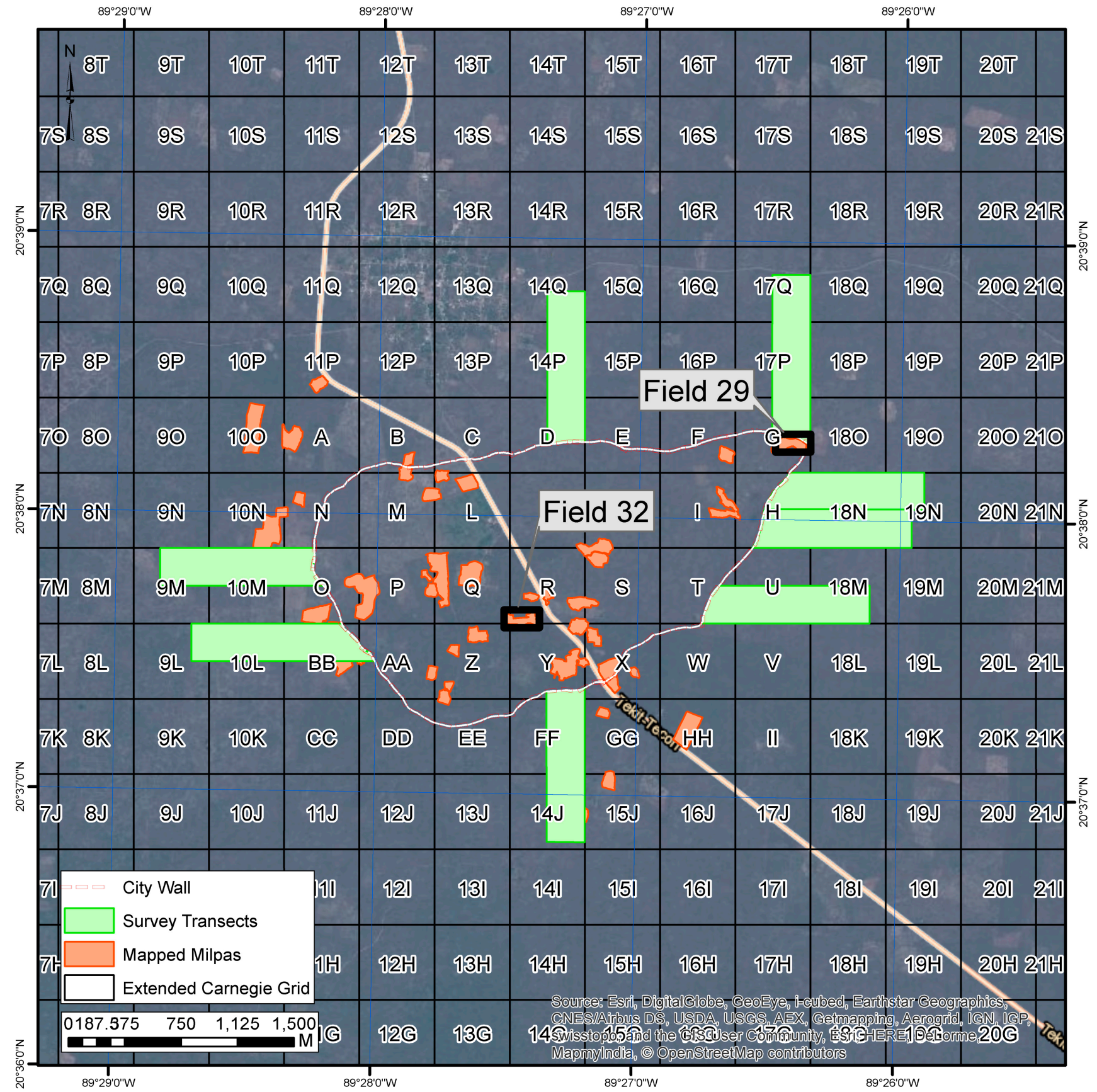

The original Carnegie map of Mayapán [23] played an important role in our investigations but we learned that there is considerable error in the sizes, orientations, and relative positions of particular features. Many structures (residences, outbuildings, public architecture) were not mapped by the Carnegie project and field walls were mapped in only a few areas (Figure 5). Errors for mapped buildings are unsystematic and vary between and within grid squares. The error is greatest beyond the city wall and in areas furthest from the principal pyramid (Q-162). The PEMY project remapped architectural features, artifact concentrations, and topography in as many open fields as possible and carefully generated corrected maps for the surveyed areas. These efforts produced an accurate spatial database for the display and analysis of the archaeological data for the sample of remapped fields. 
The resulting data were subsequently incorporated into a GIS for displaying and analyzing a variety of feature types.

Figure 5. Comparison of Carnegie and PEMY maps of fields 29 and 32.
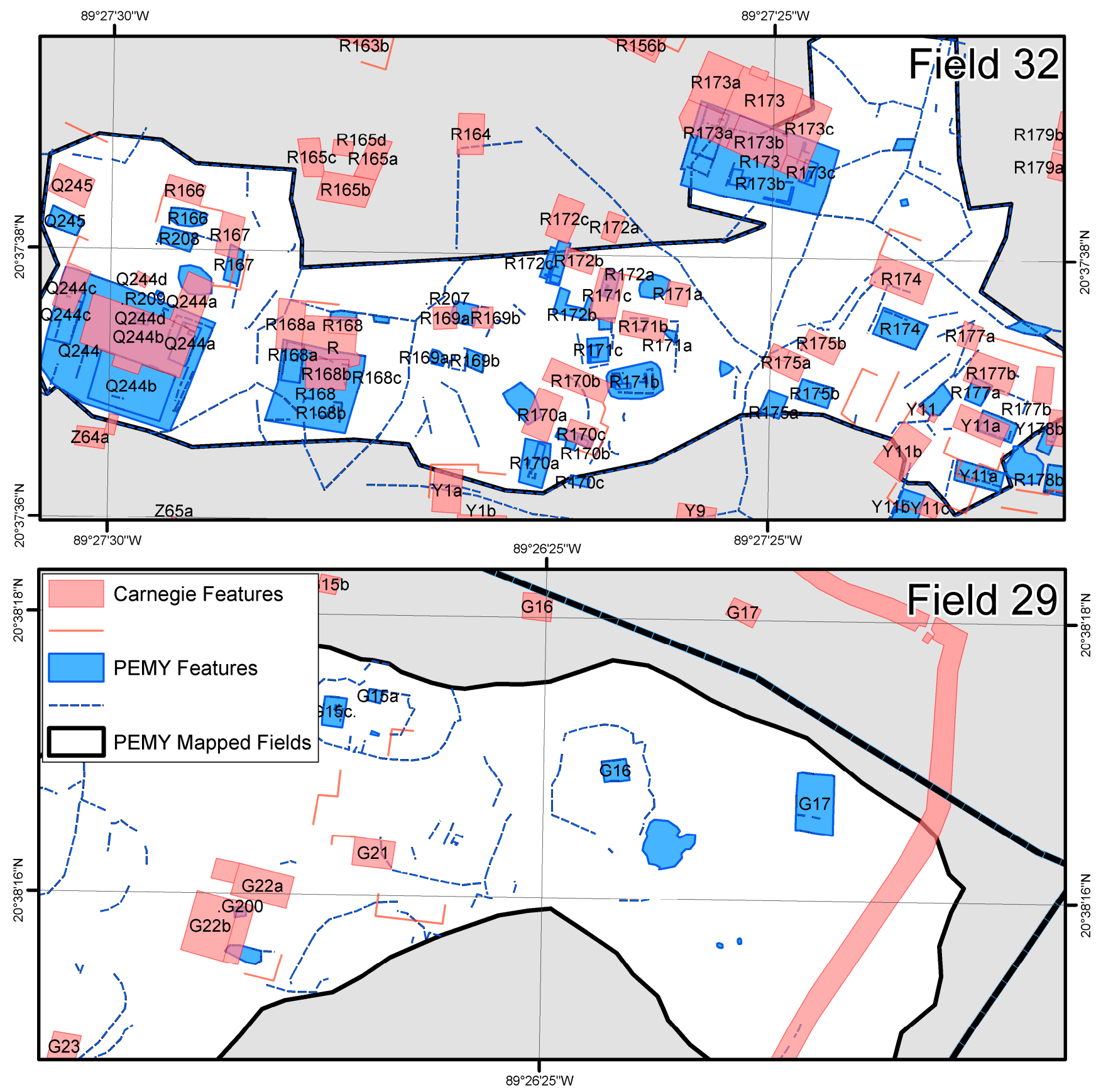

Significant conclusions from previous investigations remain tempered by the limitations of the original maps and recent sampling. The Carnegie map only includes architectural features within the city wall and within 100 meters outside the wall. In addition, the locations of many features are inaccurate and the original map does not include all features, including many off-mound structures and residential and pathway rock walls. Recent mapping has been more complete, locating many features not included in the original map, and accurate, through using contemporary survey technologies, but only covers a small sample of the city. LiDAR-based mapping promises to alleviate many of these 
problems. Specifically, LiDAR mapping can accelerate the process by covering the city and a larger surrounding hinterland. LiDAR mapping might also aid in the identification of unmapped features in the urban area and allow the revision of previous maps to improve accuracy of spatial arrangements. These improvements are necessary to achieve our major research objectives. For instance, recent demographic estimates must be confirmed or refuted by more thorough survey coverage. The amount of land dedicated to productive activities must be determined. Furthermore, up to this point, the regional context of the city has remained a mystery.

\section{The Mayapán LiDAR Mapping Project}

The Mayapán LiDAR Mapping Project is designed to help us achieve our research objectives, outlined in Section 3.1, by documenting and analyzing a $40 \mathrm{~km}^{2}$ area of settlement and environmental features around Mayapán with the use of LiDAR remote sensing technology. To address these problems, however, requires generation of a bare earth digital elevation model with sufficient detail and accuracy to allow the reliable identification of smaller features than mounded architecture. For instance, it would be valuable to be able to differentiate elite and commoner dwellings and distinguish such architectural features as ritual shrines, colonnaded halls, animal pens, limestone marl mines (sascaberas), lime plaster production features, granaries, apiaries, and field or terrace wall lines. In addition, it is valuable to identify of socially relevant environmental features such as cenotes and rejolladas (collapse sinkholes with bases above the water table). Nonetheless, we expect most laser returns to not be classified as ground points due to the nature of the low and dense vegetation in the region.

Hence, we chose to collect LiDAR data at an especially high resolution (40 laser points per square meter) to increase the likelihood of accurately capturing surface features embedded in the region's extremely dense low vegetation. Even so, the results are uneven (Figure 6). We generated a variety of surface models using the resulting two billion data points and continue exploring different ways to process the data to better filter vegetation and reveal the ground. Figure 7 [24] shows several different ways of visualizing the LiDAR data to highlight different aspects of the ground surface. There is not a single ideal way to visualize that best reveals archaeological patterns. Different visualization techniques are affected by the nature of the ground surface, vegetation, and type of feature being identified. For these examples, the original classified ground points including minimal noise are processed in Microstation and TerraScan to generate the initial DEM. The Original Ground and Low Points DEM is generated using ground points and returns that are within 0.5 meters of the elevation of the estimated ground surface. The result is a "noisier" DEM that may capture more architectural detail. Generating the Max Slope and the Max height Anomaly DEMs starts with a Surfer DEM Grid that is converted to a Matlab matrix. Matlab scripts are coded to produce the Max Slope and/or the Max height Anomaly matrices which are subsequently converted back into Surfer grids. 
Figure 6. Maps comparing LiDAR point densities on a one meter grid (points colored by type of return).
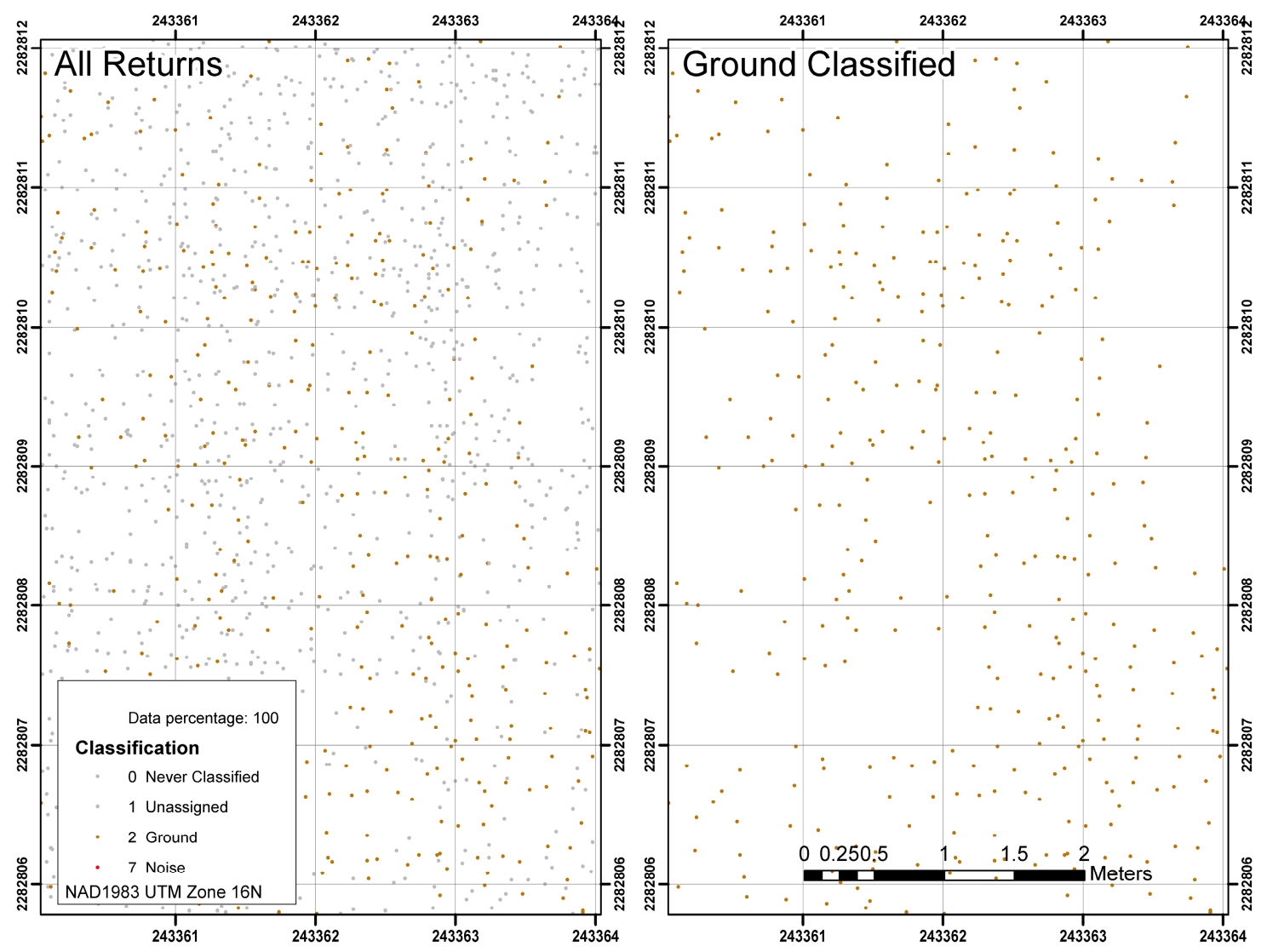

Figure 7. Comparison of several LiDAR-derived map products used for identification and mapping of archaeological features. Figure created by Juan Carlos Fernandez Diaz (NCALM-http://ncalm.cive.uh.edu) [24].

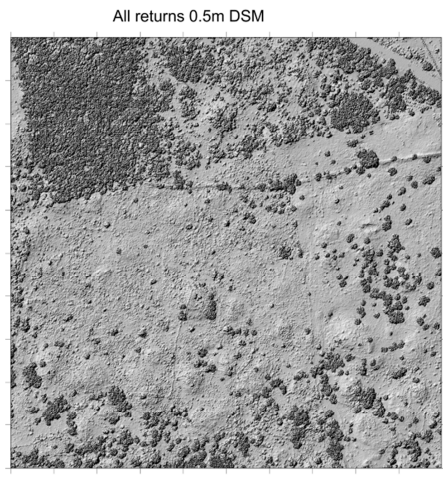

Max Slope 8 cells 8 radials

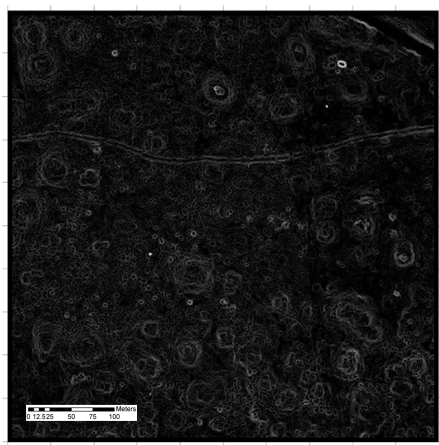

Original Ground $0.5 \mathrm{~m}$ DEM

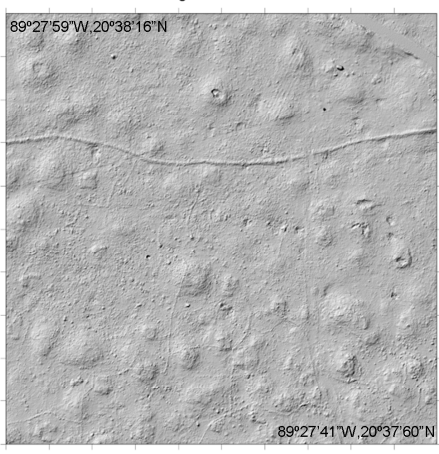

Max Height Anomaly 15 cell window

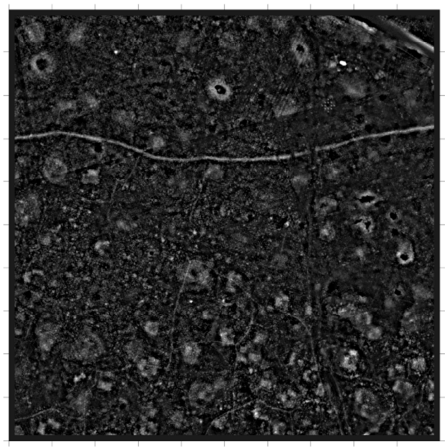

Original Ground + Low Points $0.5 \mathrm{~m}$ DEM

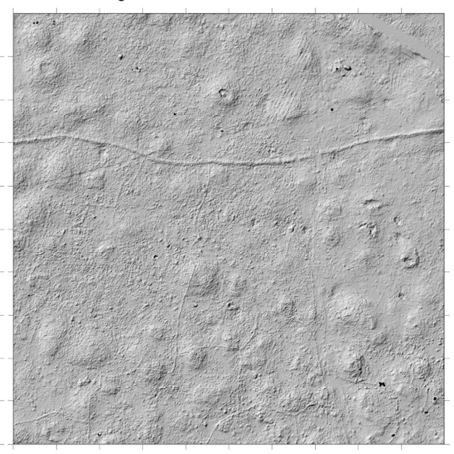

Max Height Anomaly 7 cell window

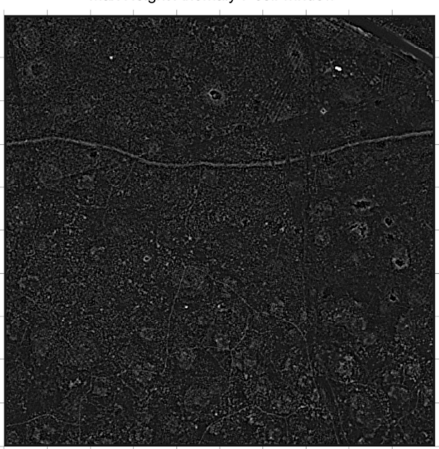


Features identified on LiDAR-based maps were ground-checked and surface collected to assess their function and chronology (Figure 8). 16.08 square kilometers were "lightly" checked (36.38\% of LiDAR area) and 38 locations were intensively checked and mapped. We used a team of four to eight people to perform a preliminary survey of sampled survey quadrants by walking transects and marking identified features on a paper copy of the DEM generated from the LiDAR data and recording details about features in a field notebook. Intensively checked areas consisted of clusters of one to three dwelling groups; they were cleared of vegetation and examples of domestic architecture were mapped with tape and compass. GPS coordinates were recorded for the locations as well as being marked on a paper copy of the LiDAR-based DEM. Surface collections were conducted to assign chronology and function to checked locations. We also conducted test excavations at a sample of intensively mapped locations to provide a further basis for estimating the time periods of occupations. Artifact analysis focused on chronological markers and evidence of function and production activities.

Figure 8. Map of areas checked by pedestrian survey and the intensive sample zones.

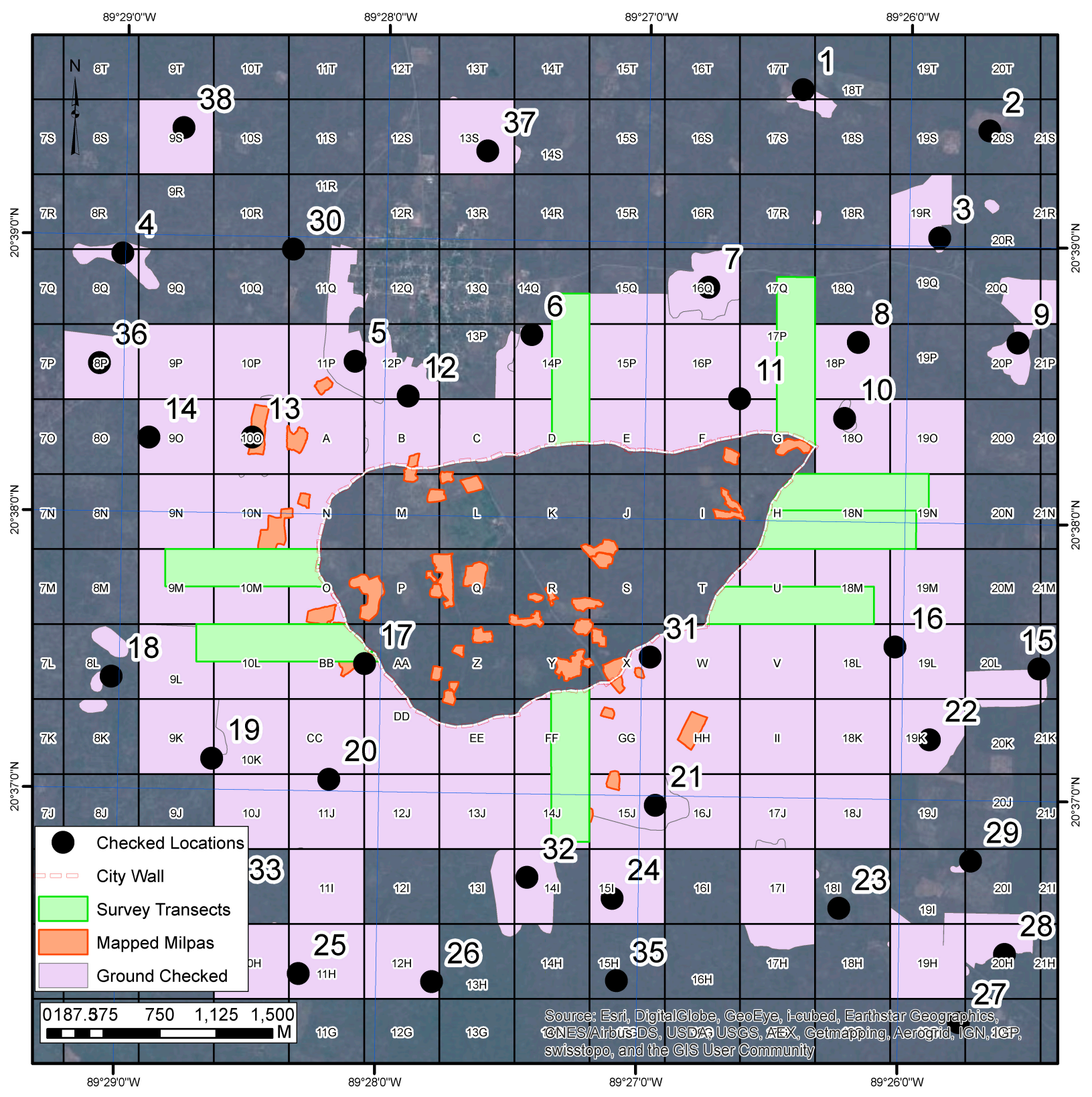


Our prior experience mapping within the city wall and in the eight transects $(1 \mathrm{~km} \times 250 \mathrm{~m})$ in the sample area and outside the city wall enabled us to construct a typology of feature types and the time periods with which they tend to be associated. This typology is being checked, refined, and expanded by further ground-truthing and test excavations.

\section{Specific Objectives}

Our current work, the Mayapán LiDAR Mapping Project, is guided by five specific research objectives:

- Estimate demographic organization of the complete city and its hinterland.

- Update and complete the city map.

- Reconstruct settlement and production activities outside the city wall.

- Reconstruct the regional administrative system.

- Document long-term settlement changes.

The first objective is to improve estimates of the size and population of the Postclassic urban center and provide the first estimates of regional population; estimates projected from initial transects outside the city wall raised the city population estimate of $10-12,000$ to $15-17,000$ individuals [3]. However, settlement density is likely not constant and this work provides the data for more accurate demographic reconstruction.

The second objective is to enhance our data for the analysis of the organization of Mayapán's densely-packed residential zone within the $9.1 \mathrm{~km}$ circumference of the city wall. The new data permit full analysis of the spatial distribution of the following characteristics: dwelling size, numbers of dwellings per group, the number and type of ancillary buildings in houselots, the size of domestic solares (walled houselot spaces), other walled features (pens, enclosed fields, pedestrian lanes traversing the city), cenotes, open plaza spaces (recognizable as areas not divided by walled features), and spatial clustering relative to proximity to focal architecture. These variables have been analyzed for our subset of fully mapped areas of the city, and we will extend this analysis to $100 \%$ of the walled area as well as the area outside the wall. These data permit the analysis of degree of residential differentiation by demographic, metric, social (stylistic), or economic factors as well as the degree to which planning features (focal nodes, thoroughfares) integrated residential zones with one another and with the city as a whole.

The third objective is to analyze the occupational patterns within a $3.5 \mathrm{~km}$ radius of the city wall, with specific attention to strategies for the utilization and management of diverse resources essential for sustaining the city's population. Cenotes (and other aquatic features), soil types, and elevation may be correlated with varying settlement or cultivation intensity as well as specialized extraction of clays, lime, or forest resources.

The fourth objective is to document evidence for political integration of settlement outside of Mayapán's wall. Earlier surveys suggest that this zone is punctuated by administrative features such as elite residences, colonnaded halls, temples, and non-residential shrines [16,21]. The distribution of regularly-spaced and aligned focal nodes is also identified within the walled settlement and we have argued that activities at these facilities helped to link residents to governing elites and the polity as a whole. More distant Postclassic public architecture outside of Mayapán suggests that the outer 
landscape included satellite settlement clusters of secondary centers, but full mapping and chronological assessment is necessary to evaluate the relationships of these sites to the city.

The fifth objective is to document longer-term changes in settlement organization and resource use in earlier periods that provide the historical context for the foundation of the Mayapán state. Initial transects suggest that populations of the Preclassic through Terminal Classic Period lived in dispersed clusters of agrarian hamlets that favored major water sources. Terminal Classic Period settlement is the most ubiquitous in outer Mayapán; transect data implies that these agriculturalists lived near major water sources and may have established cultivation practices of direct historical importance to those adopted by the subsequent Postclassic city.

\section{Preliminary Results}

\subsection{City and Regional Demography}

We are close to determining the extent of the city and nature of regional settlement by mapping Postclassic residences and associated features. Settlement was present throughout each of the $16 \mathrm{~km}^{2}$ subjected to pedestrian survey and our intensively survey localities resulted in the identification of 24 clustered areas of habitation. Visual examination of the LiDAR DEM and groundtruthing in a sample of the area reveal that these clusters are joined together by continuous dispersed settlement. Thus, we infer that the settlement clusters are simply portions of largely continuous settlement throughout the study area.

Residential density varies across the study area. The mean grid square density of structures per hectare is 2.5 (pph). Assuming two structures per hectare are dwellings, this equates to a general estimate of $6 \mathrm{pph}$.

We are close to generating definitive estimates of the city's population and settlement extents. Brown [2] suggested that the walled portion of Mayapán was home to approximately 15,000 based on the number of residences he estimated to be unmapped on the Jones-Carnegie map. Russell [16] estimates 15-17,000 residents by simply adding Carnegie-mapped residences to the average density found in eight transects outside of the wall and projected to the entire 500 meter circumference of surveyed and unsurveyed areas beyond the wall. If both estimates are correct, we may predict that Mayapán housed around 20,000 people. Our new data show continued occupation outside the city wall in all directions, but to varying densities and distances. Figure 9 shows a gradual decrease in the density of dwellings with increased distance west and north from the city wall, but the fall-off varies in different directions. Russell's transect densities appear to be representative of the entire circumference of the city wall.

Of course, further investigations are necessary to understand the underlying forces creating such uneven occupational densities and distributions outside the wall. Potential factors to investigate include variation in production activities, such as in the area of a cluster of lime production features in a low-density area, and relative proximity to cenotes; Mayapán's residents on average lived within $500 \mathrm{~m}$ of a water-bearing cenote. Other potential explanatory factors could include soil depth, soil quality, or elevation. For instance, doctoral student Caroline Antonelli is conducting overall resource assessment study as part of her dissertation research. 
Figure 9. Map of varying density and distance of settlement outside the city wall.

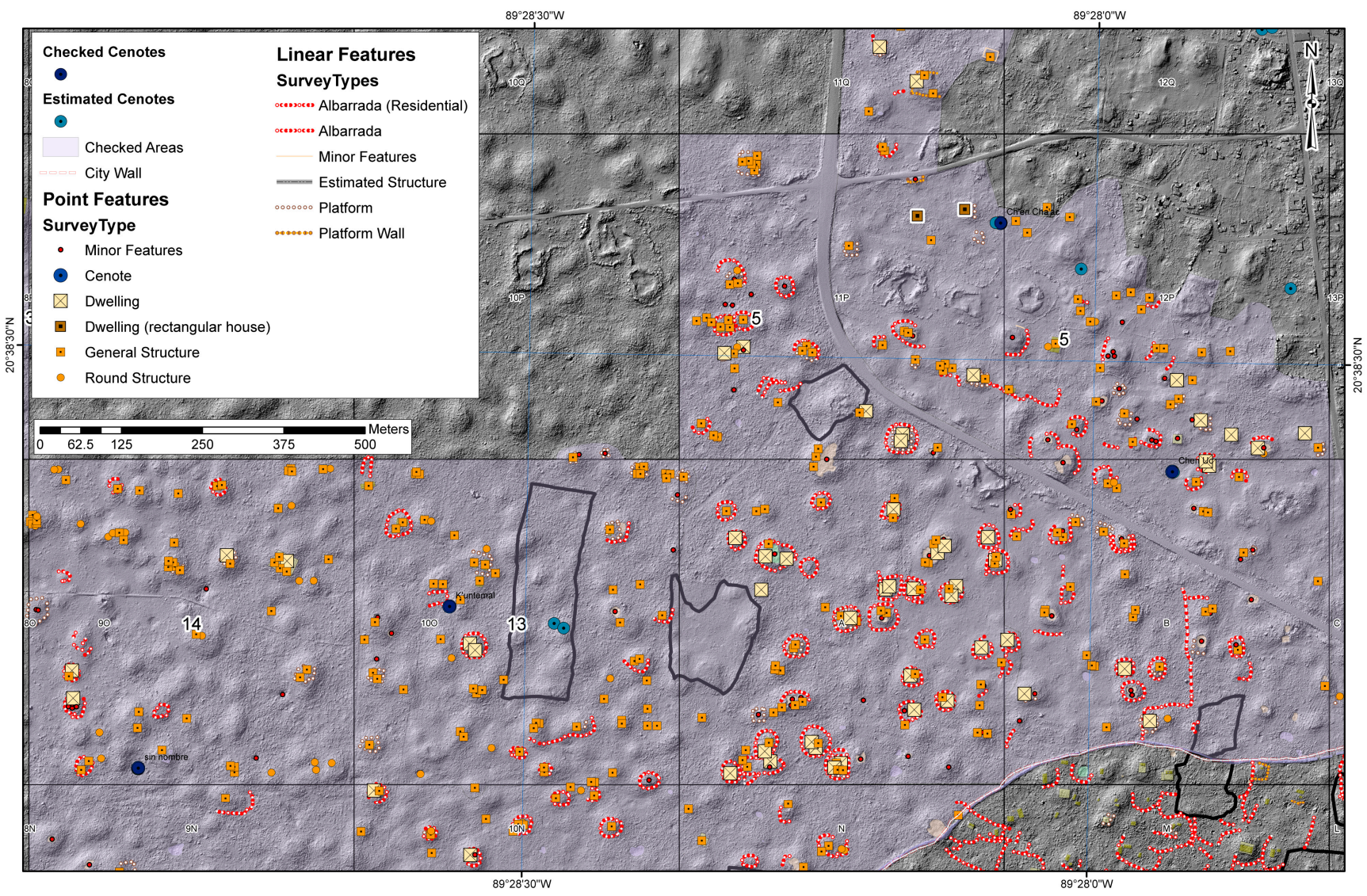

\subsection{Complete Map of Urban Organization}

Hare is currently performing an in-depth analysis of the organization of the densely inhabited walled residential zone. Figure 10 shows a preliminary redrawn map of the northwest quadrant of the urban center based on the LiDAR DEM. All boundary walls (albarradas) are drawn based on the LiDAR DEM since they were not mapped by previous projects. Architectural features mapped by previous projects are moved, rotated, and resized based on the LiDAR DEM. The Carnegie mapped features do not easily match up with those visible in the LiDAR map and many additional features are visible that have not been mapped previously. Most importantly, preliminary work indicates that it is possible to map much of the complex network of walls defining residential houselots, animal pens, open spaces, and pathways within the city. These walls define community structure, controlling and limiting movement through the urban environment. Completion of a new city map combining information from all previous mapping projects will allow us to greatly expand our recent investigations of urban organization.

Mapping the network of pedestrian pathways throughout the city is revealing the nature of Mayapán's urban structure. Smaller and more indirect trails between houselot boundary walls were probably of importance primarily to nearby residents. Larger pedestrian thoroughfares tend to be more direct, broader, and they connect key focal nodes such as gates, cenotes, monumental architecture, and/or open plazas [25]. We anticipate that larger thoroughfares will be found extending from Mayapán's gates toward focal nodes in the interior (as observed for Gates D, H, AA). Major and minor lanes may also be useful in determining neighborhoods at Mayapán. Although focal architecture is 
fairly regularly distributed across the city and may have served as residential zone nuclei, this association is hypothetical. Paths have great potential to determine city divisions, which may have enclosed residential units meaningful to Mayapán's occupants or may have been imposed by administrators without consideration of social or historical factors influencing the settlement zone [26]. Strong indicators of residential clustering within lane-divided sectors may suggest synchrony between social groups and paths; if paths disrupt spatial clustering, then they may have been arbitrarily imposed. Such distinctions may be obscure, but are worth investigating.

Most previous analyses of Mayapán's urban structure were based on the Carnegie map, and indicate a chaotic and purposeless distribution of architectural features. Mapping the network of residential and pathway walls will make it possible to better understand the forces determining the city's organization and layout.

Figure 10. Example map of urban settlement within the city wall.

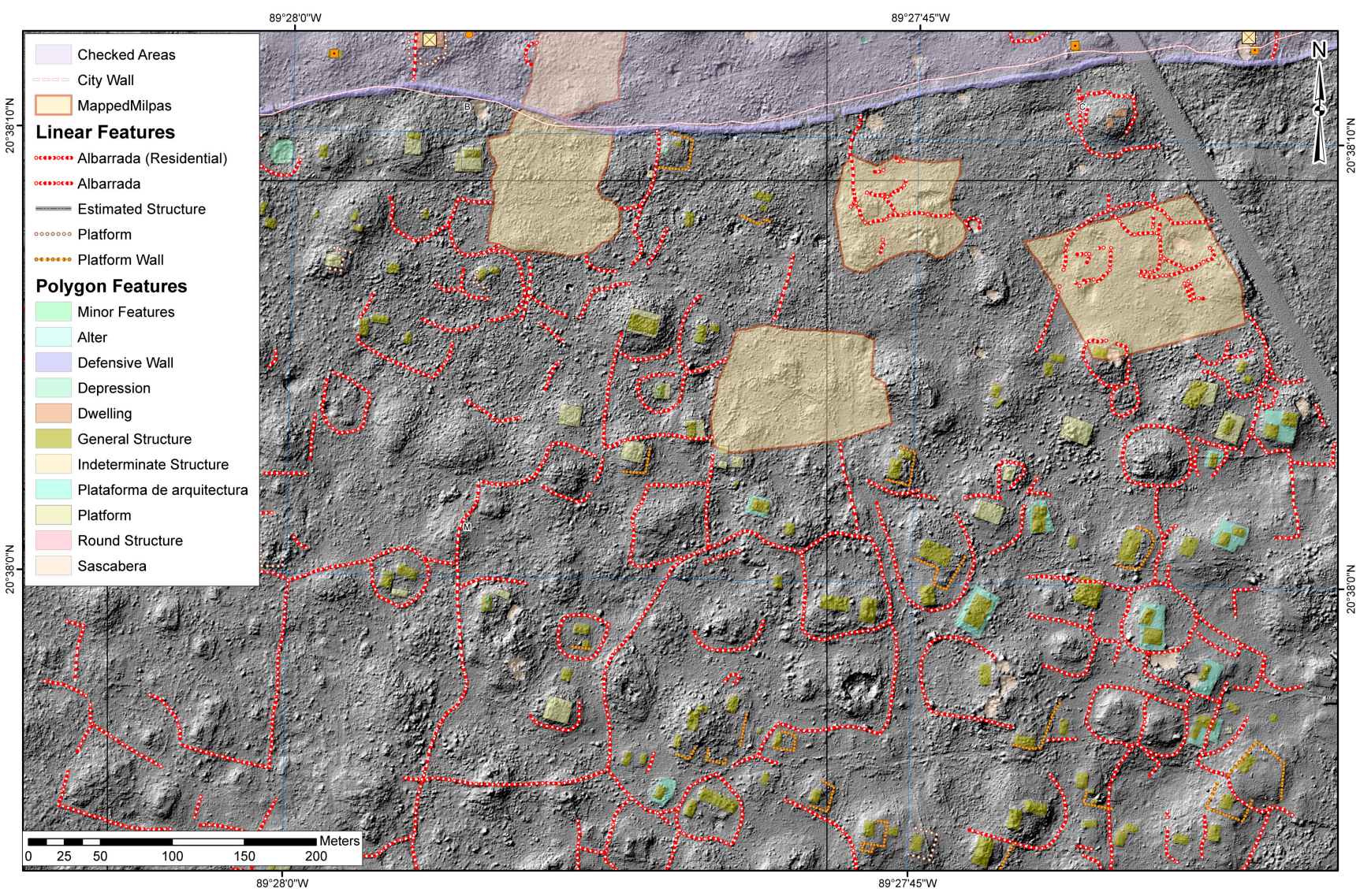

We previously statistically analyzed domestic group size, numbers of dwellings per group, and relationships between these variables and sizes of walled houselots or nearby walled fields [27]. Based on our sample of small mapped fields, there is little correlation among these variables with each other, with social status, or according to areas of the city such as proximity to the monumental zone or city wall. Residences are less dense near the city wall, but solare (walled houselot spaces) sizes are surprisingly unrelated to the amount of available space. Figure 11 shows a bare-earth DEM of a Mayapán-style houselot within the city wall. The residential property wall surrounds two structures on a platform, an additional off-platform structure, and several architectural walls. In this case, even the distinctive Mayapán benches are visible on the largest structure. Tightly constricted solares on 
hillocks that provide greater privacy tend to be near or outside the city wall or near busy public places such as the plaza in Square K. The comprehensive dataset will allow us to evaluate the validity of this patterning.

It will also enable us to analyze residential clustering; Brown [2] defines a cluster as domestic groups sharing a boundary wall and proposed that these indicate relevant socioeconomic units. The sizes of our sample fields were too small in area for the analysis of clusters. Such families may have had greater opportunities for growth and expansion. Mayapán's high proportion of isolated residences distinguishes it from many Classic Period cities [28]; however, these single dwellings may be more appropriately analyzed from the perspective of the houselot cluster.

Figure 11. Example of a mapped solare or walled houselot.

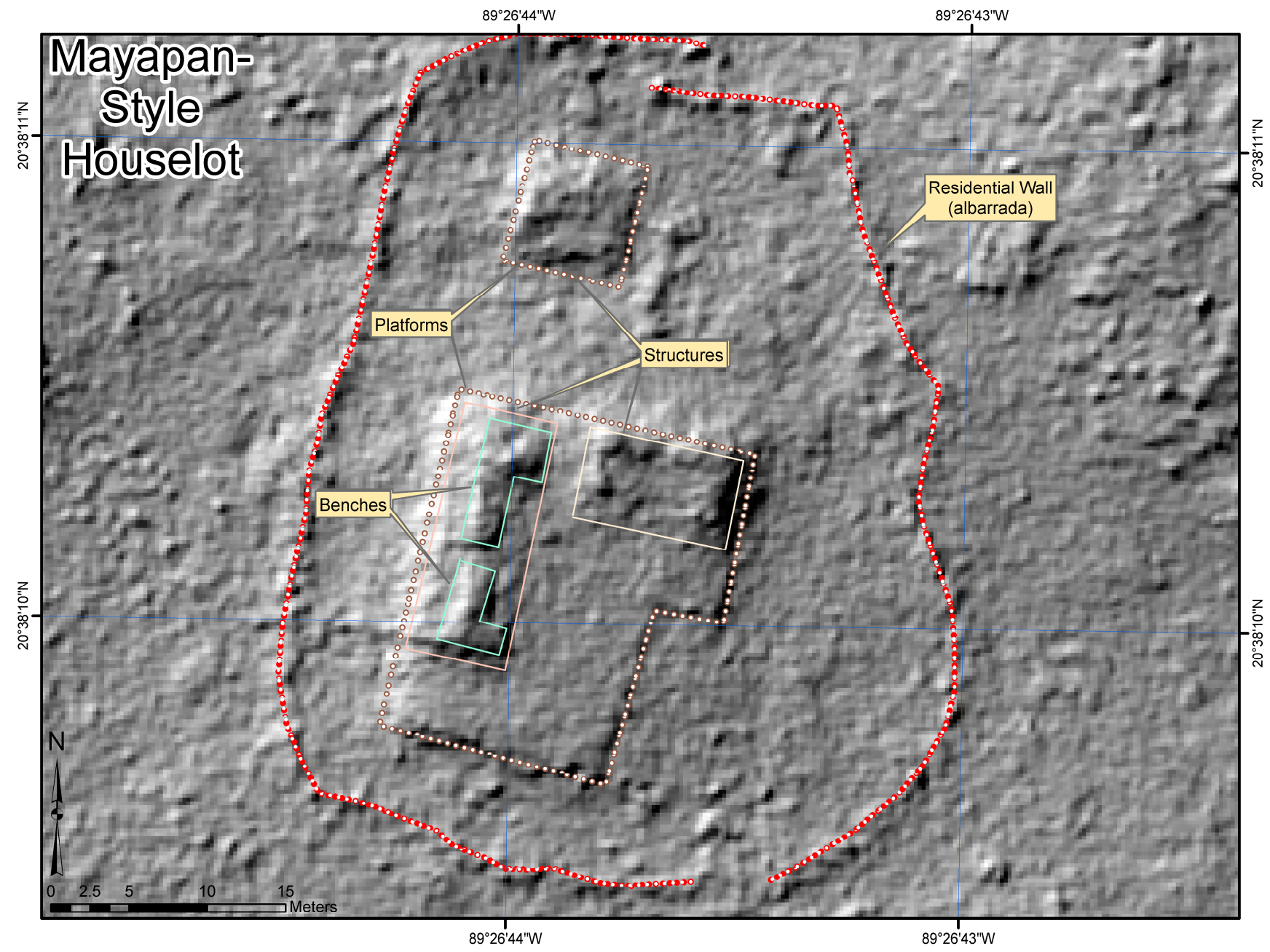

\subsection{Regional Distribution and Concentration of Residential, Productive, and Administrative Activities}

Objectives \#3 and 4 together address the distribution and concentration of residential and productive activities outside of the city wall. Even preliminary study of the LiDAR map revealed numerous nucleated clusters of elite and administrative architecture, commonly associated with natural features such as cenotes (Figure 12). Cenotes, and other types of deep holes, are easy to identify using the LiDAR data due to the extreme change in elevation across short distances. Mayapán is located near a ring of cenotes, associated with the rim of the Chicxulub crater wall, which may have been attractive 
for Classic era colonization. Figure 12 shows approximately 120 cenotes found outside of Mayapán's city wall. Unfortunately, we lack comparative data that would reveal whether this cenote density is especially unique.

Figure 12. LiDAR-generated digital elevation model (DEM) of the survey area with identified nucleated centers and cenotes in Mayapán's periphery.

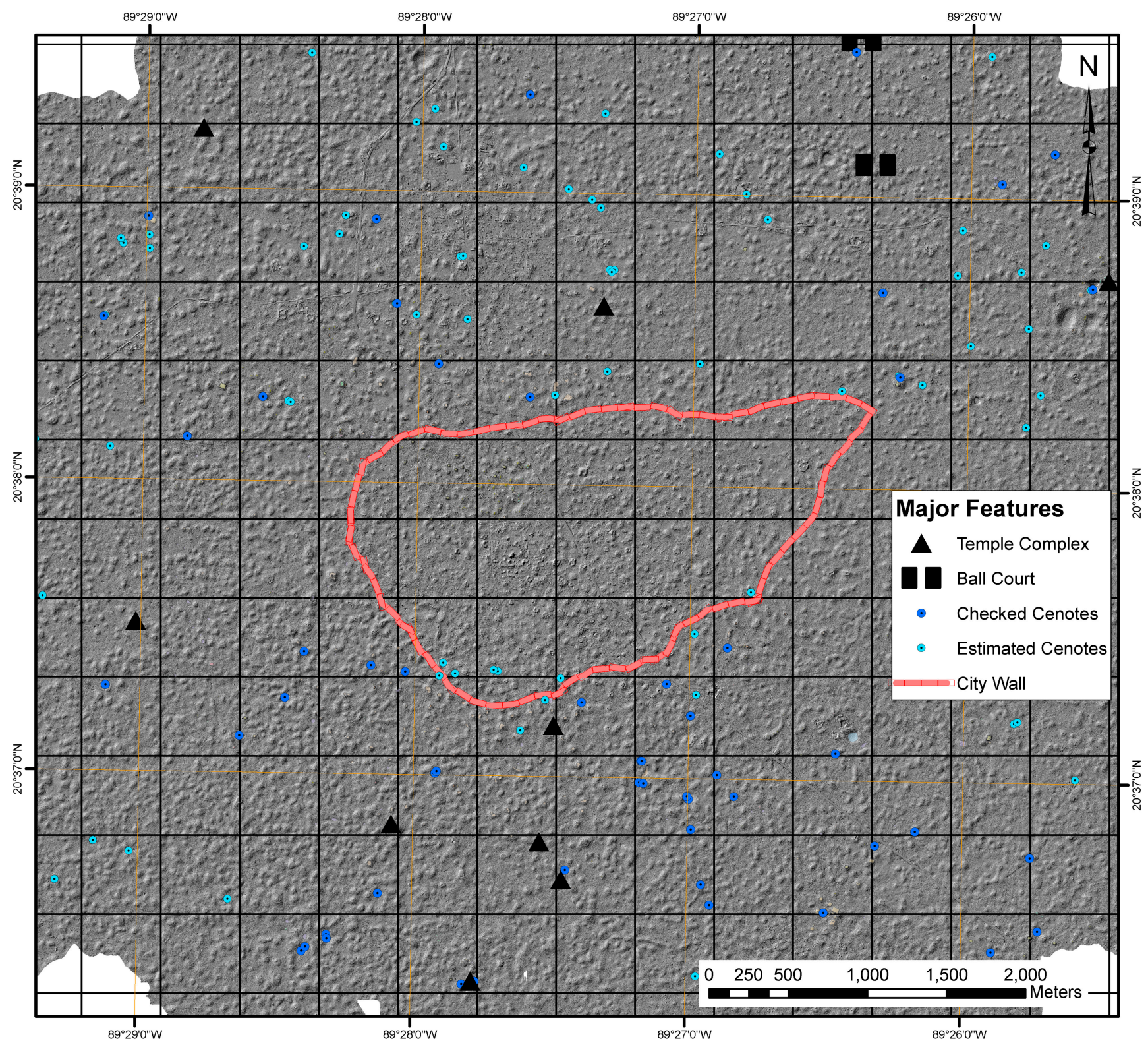

It is expected that neighborhoods developed unevenly according to resource distribution (cenotes, agricultural soil depth linked to elevation, presence of hillocks preferred for residences, etc.) and also according to economic or symbolic factors. Focal nodes such as outlying temples or halls may have been built as part of planned settlement zones, or they may have weak residential associations [29]. Proximity to historical routes for visitors to the city may have also drawn settlement; major gates near historical trails indicated on the Carnegie map (such as Gates D, EE) may have been near roads in use during Mayapán's era. Nonresidential features identified as low stone alignments that are not rectangular or square are not organized into house groups and are not within the size ranges identified 
for houses. These tend to be asymmetrical. Pens are small enclosures usually attached to houselot boundary walls. Pens can be single or include multiple spaces. Fields may or may not be associated with houselot walls and do not enclose domestic structures; they can be partly or fully enclosed by low wall alignments. Lime burning features are round alignments with much carbon and small burnt limestone cobble wasters contained within them.

Elite residences may be dispersed outside of the wall, and we have argued that within the wall, these housed intermediate officials who coordinated residential zone activities. Russell [21] found one colonnaded hall outside of Gate G; more such features exist around Mayapán's periphery. Such halls may have helped to administer neighborhoods or they could have had a role in control and taxation of merchants entering the city as proposed for non-residential plazas at the sacbe termini of Caracol [30,31]. Once we determine the number and location of such features, we can begin to build hypothetical models regarding their function that will be the basis for future excavation and testing to determine associated activities. Further evidence for city planning would be reflected by the regular spatial distribution of outlying elite residences or public buildings. A regular dispersion of the features would suggest strategic oversight. Alignments of public buildings with other focal nodes of the city (as observed within the wall) would also suggest planned coordination.

A satellite center is expected to exhibit at least one monumental building and a residential cluster that is spatially disconnected from the Postclassic residential sprawl outside of Mayapán's wall. While not quantified, a "spatial disconnection" suggests an area with a low density of architectural features separating the areas of settlement. Robert Smith [7] identified two temple-cenote groups located $1 \mathrm{~km}$ to the north (Tichac, under modern Telchaquillo) and $1 \mathrm{~km}$ to the south (Santa Cruz); nine others are reported by Ruppert and Smith [32]. Most of these sites were in our LiDAR survey area, and were revisited. The majority had architecture of Terminal Classic date with significant Postclassic modification and occupation; some, like Jabah, were built in the Postclassic Period. Other new temple-cenote groups were revealed in our own reconnaissance or LiDAR ground checking efforts, such as the Postclassic era temple-cenote center of Rancho San Ángel, $1.2 \mathrm{~km}$ west of Mayapán. Beyond the survey area, larger monumental centers constructed in the Classic Period were visited to the east, west, and south, including Itzin Kan, San José Pixyah, and Xpakai with temples of 8-10 meters in height and massive monumental platforms, suggesting an intermediary status for the smaller groups within the LiDAR survey zone. The LiDAR map reveals dense, relatively continuous Classic and intermediate Postclassic settlement around these outlying features, as well as the number of structures clustered near these centers. Given the consistent distance and Russell's findings that Mayapán's housing does not extend far beyond $500 \mathrm{~m}$ from the wall, we predict that these sites served as satellite centers for Mayapán, possibly marking Pre-Columbian trails or roads to important subject towns of interest. It is possible that some of these cardinal satellite centers were incorporated into quadripartite symbolic planning and organization of settlement.

\subsection{Long-Term Settlement History}

The LIDAR map and survey identified multiple extensive non-Postclassic settlements outside the city wall, of which many are associated with Late-Terminal Classic materials. Satellite centers (described above) in the sample zone were constructed in the Classic Period. A major finding of 
the LiDAR survey is that ancient populations preceding Mayapán, in the Late Classic and Terminal Classic Periods, were abundant. The entire survey area was occupied at this time and residential structures continue beyond the edges of our map. Pedestrian ground survey was necessary to check the accuracy of the LiDAR map, as unfortunately, small rectangular or apsidal houses, especially those located in low-lying areas, were not detectable on the LiDAR DEM. Such features frequently do not extend more than $10 \mathrm{~cm}$ above the ground surface and can be covered by soil deposition when located in low-lying areas. In contrast, houses built with large stone foundations or that were framed by property walls or rubble platforms were clearly discernible.

In many localities, settlement exhibits different house styles and dates to various time periods. Larger residential platforms and public architecture, including temples, were built and used over long periods of time, from the Late Preclassic through Postclassic or Colonial periods. Much of the occupation outside of the Postclassic city dates to Late and Terminal Classic; pottery from these periods is found in all collections. If we project the average Classic Period settlement density from ground-checked squares to the entire survey area, there may be 8000 houses of Classic Period age, representing a potential population of 24,000 people outside of the area enclosed by the city wall of Mayapán. In contrast, within the walled city of Mayapán itself, where the majority of all occupation dates to the Postclassic era city and people lived in clusters as dense as 77-126 pph.

Classic Period settlement appears to be characterized by extensive zones of terraformed hill platforms. Their dispersed nature is related to the fortuitous location of small hills or altillos and represents a pattern of low-density settlement similar to that observed for garden cities of the Classic Period. Terraforming involves reshaping and amplifying a natural topographic feature. Massive rectangular residential platforms were formed with the addition of tons of rock fill and retaining walls. Rubble fill was used to flatten and extend the upper surfaces of the hill. Associated elite structures tend to be higher and more rectangular. Small terraformed hills support dwelling groups of one or two houses and storage rooms. Variation in height, area, elaboration, and proximity to ritual architecture seems to differentiate commoner and elite groups. Some examples are particularly impressive, especially when original hills were of significant height. Occasionally, such groups housed a large rubble shrine.

The implications of our findings of ubiquitous, yet dispersed Classic Period residences in the LiDAR zone are significant. This part of the Yucatecan Plains did not host any Rank I, II, or III centers of this period [33]. The LiDAR image reveals substantial investment in terraforming small hills into quadrangular hill platforms with large retaining walls and impressive quantities of rock fill. This investment in housing suggests that the relatively rural Classic era populations of the survey area were living year round in the area. Elsewhere in Yucatán, populous countryside settlement was suggested to be of a seasonal nature [34].

Further analysis of our mapped data will document the extent and density of that settlement and enable comparisons to Mayapán. Other Classic era dwellings seem to form dispersed clusters near major cenotes; these were likely agricultural hamlets and contrast with Mayapán's nucleated residential strategy. Full mapping will assess these patterns' accuracy. Earlier surface features (of Preclassic or Early Classic Period date) will be harder to identify from surface survey, but the soil around Mayapán is shallow and gopher burrowing often brings earlier material to the surface. Our 
prior surface collections have been able to detect traces of earlier occupation and in some cases; earlier settlement is stratified horizontally.

\section{Conclusions}

The Mayapán LiDAR Mapping Project is incomplete and the results presented are preliminary, but they already provide insights into the lives of ancient people in and around the city. The ancient, as well as modern inhabitants, lived in a complex symbolic and practical relationship with the natural world. The physical landscape of the Postclassic Maya political capital of Mayapán was transformed by the practices of house construction, farming, foraging, and hunting as well as by architecture that delineated political, economic, and sacred geography. The surface features, caves, and cenotes of Mayapán and the surrounding region represent the vestiges of a fully-altered anthropogenic environment from at least the seventh through fifteenth centuries A.D. Today, the cognitive maps of local inhabitants continue to differentiate the forest according to named cenotes of ancient significance. Application of LiDAR to our research provides a new and powerful tool for emphasizing how human life was shaped by the natural world, and conversely, ways that human imprints permanently reconfigured their physiographic context.

Our research is beginning to calculate human impacts and responses to the physiographic, geological, faunal, botanical contexts of Mayapán's realm and its predecessors. In summary, the themes of human ecology and anthropogenic landscape transformation of ancient Mayapán and have emerged as essential components of our research. Every line of inquiry, whether it relates to the organization of the economy, politics, social structure, or religion brings recognition of the seamless relationships between humans and the long term historical geology and ecology of this area. A greater understanding of the world view and religion of these ancient inhabitants arises from evidence that the symbolic realm was embedded more broadly in the wholesale domestication of forests, fields, and houselots to meet the concerns of daily life.

All the information available from the two billion LiDAR data points collected has yet to be extracted and analyzed. We continue to explore new ways to filter and visualize the data for better identification of ancient human and natural features. We look forward to completing the analysis of resulting LiDAR and field data, drafting a complete map of the urban settlement, and placing Mayapán into its regional context. Additionally, given the quantity of data acquired, we are also exploring the potential for automation of feature extraction.

This project also paves the way for expanding and enhancing the use of LiDAR in archaeology. Our preliminary results demonstrate both the benefits and the limitations of LiDAR. The technology made it possible to rapidly expand both our knowledge of Mayapán's extents beyond the 4.2 square kilometers within the city wall and the detail at which we perceive the urban and rural settlement organization across a region. We also encountered the limits of current LiDAR technology. We collected data at 40 points per square meter to provide a bare-earth DEM with a resolution sufficient to identify small and subtle archaeological and environmental features. The results vary depending on local vegetation and the nature of the objects mapped. Thus far 3429 features have been newly identified. 245 apsidal structures, 549 round structures, 14 temples, 274 sascaberas, 123 cenotes, and over 1600 rectangular houses are visible in the bare-earth DEM, but ground checking also shows that 
many low-relief features, such as apsidal structures, are invisible. LiDAR technology is not static, however. We are exploring the potential of enhanced technologies such as full-waveform LiDAR for better filtering of vegetation for the generation of more accurate and higher resolution bare-earth DEMs.

\section{Acknowledgments}

We thank the team at the National Center for Airborne Laser Mapping (NCALM-http://ncalm.cive.uh.edu) for flying the survey and continuing to collaborate in exploring better ways to use LiDAR for mapping archaeological remains under heavy vegetation. Research at Mayapán has been supported by grants from the Foundation for the Advancement of Mesoamerican Studies, Inc., the National Science Foundation (\#1018919, \#1069128), \#1144511, National Geographic's Committee for Research and Exploration (\#8598-08), the Department of Anthropology at the University at Albany-SUNY, and the the Office of Research and Sponsored Programs at Morehead State University. This work was performed with the gracious permission of the Consejo de Arqueología, INAH, México, D.F.

\section{Author Contributions}

The three authors co-directed the fieldwork. Timothy Hare coordinated the LiDAR survey, processed and mapped the LiDAR data, and directed mapping activities. Marilyn Masson coordinated test excavations, sampling for ground truthing, and managed laboratory activities. Bradley Russell coordinated ground truthing field teams, oversaw intensive sampling, and directed survey of cenotes.

\section{Conflicts of Interest}

The authors declare no conflict of interest.

\section{References}

1. Smith, A.L. Residential and associated structures at Mayapán. In Mayapán Yucatan, Mexico; Pollock, H.E.D., Roys, R.L., Proskouriakoff, T., Smith, A.L., Eds.; Carnegie Institution of Washington Publication: Washington, DC, USA, 1962; Volume 619, pp. 165-320.

2. Brown, C.T. Mayapán Society and Ancient Maya Social Organization. Ph.D. Dissertation, Tulane University, New Orleans, LA, USA, 1999.

3. Russell, B.W. Postclassic Maya Settlement on the Rural-Urban Fringe of Mayapán, Yucatan, Mexico. Ph.D. Dissertation, University at Albany (SUNY), Albany, NY, USA, 2008; pp. 689-706.

4. Pope, K.O.; Ocampo A.C.; Kinsland, G.L.; Smith, R. Surface expression of the Chicxulub Crater. Geology 1996, 24, 527-530.

5. Winemiller, T.L.; Ochoa-Winemiller, V. GIS in archaeology: The human/environment interface of Maya settlements. GIM International, 29 December 2006, Volume 20. Available online: http://www.gim-international.com/issues/articles/id603-GIS_in_Archaeology.html (accessed on 5 October 2010).

6. Pollock, H.E.D., Ed. Mayapan, Yucatan, Mexico; Carnegie Institution of Washington: Washington, DC, USA, 1962; Volume 619. 
7. Smith, R.E. The Pottery of Mayapán Including Studies of Ceramic Material from Uxmal, Kabah, and Chichen Itza; Peabody Museum of Archaeology and Ethnology: Cambridge, UK, 1971; Volume 66, p.66.

8. Weeks, J.M. The Carnegie Maya II: The Carnegie Institution of Washington Current Reports, 1952-1957; The University Press of Colorado: Boulder, CO, USA, 2009.

9. Shook, E.M. The Great Wall of Mayapan; The Carnegie Institute of Washington: Washington, DC, USA, 1952.

10. Bullard, W.R. Property Walls at Mayapán. In Current Reports; The Carnegie Institute of Washington: Washington, DC, USA, 1954; Volume 54, pp. 276-277.

11. Bullard, W.R. Boundary walls and house lots at Mayapan. In Current Reports; Department of Archaeology, The Carnegie Institution of Washington: Washington, DC, USA, 1954; Volume 13, pp. 234-253.

12. Bullard, W.R. Residential Property Walls at Mayapan; Department of Archaeology, The Carnegie Institution of Washington: Washington, DC, USA, 1952.

13. Dahlin, B.H.; Ardren, T. Modes of exchange and regional patterns: Chunchucmil, Yucatan, Mexico. In Ancient Maya Political Economies; Feinman, G.M., Nicholas, L.M., Eds.; AltaMira Press: Walnut Creek, CA, USA, 2002; pp. 249-284.

14. Kurjack, E.B. Prehistoric Lowland Maya Community and Social Organization: A Case Study at Dzibilcháltun, Yucatan, Mexico; National Geographic Society, Tulane University, Program of Research in Yucatan: New Orleans, LA, USA, 1974.

15. Fletcher, L. Coba and Mayapan: A Comparison of solares, household variation, socio-political organization and land tenure. In Coba: A Classic Maya Metropolis; Academic Press Studies in Archaeology: New York, NY, USA, 1983; pp. 121-131.

16. Peraza Lope, C. Mayapán, Ciudad-capital del Postclásico. Arqueol. Mex. 1998, 2, $48-53$.

17. Peraza Lope, C.; Delgado Kú, P.; Escamilla Ojeda, B. Trabajos de Mantenimiento Y Conservación Arquitectónica en Mayapan, Yucatan: Informe de la Temporada 1998; Centro INAH Yucatan: Mérida, México, 2003.

18. Peraza Lope, C.; Delgado Kú, P.; Escamilla Ojeda, B. Trabajos de Mantenimiento Y Conservación Arquitectónica en Mayapan, Yucatan, Informe de la Cuarta Temporada: 1999-2000; Centro INAH Yucatan: Mérida, México, 2003.

19. Masson, M.A.; Peraza Lope, C.; Hare, T.S. Proyecto Los Fundamentos del Poder Económico de Mayapán, Temporadas 2001-2004, Informe Final Para el Consejo Nacional de Arqueología de México; UAlbany SUNY and Centro INAH Yucatán: Albany, NY, USA, 2008.

20. Masson, M.; Peraza, L.C.; Hare, T.S. Russell, B.W. Los Fundamentos del Poder Economico de Mayapan, Temporadas 2008-2009, Informe Final Para el Consejo Nacional de Arqueología de México; UAlbany SUNY and Centro INAH Yucatán: Albany, NY, USA, 2012.

21. Russell, B.W. Colonnaded hall group discovered outside Mayapán City Walls. Mexicon 2007, 29, 93-94.

22. Russell, B.W.; Dahlin, B.H. Traditional burnt-lime production at Mayapán, Mexico. J. Field Archaeol. 2007, 32, 407-423.

23. Jones, M. Map of Mayapán. In Mayapán, Yucatan, Mexico; Carnegie Institute of Washington: Washington, D.C., US, 1962; p. 619. 
24. The National Center for Airborne Laser Mapping. Available online: http://ncalm.cive.uh.edu (accessed on 12 August 2014).

25. Hare, T.S.; Masson, M.A.; Peraza Lope, C. The urban cityscape. In Kukulkan's Realm: Urban Life at Ancient Mayapan; Masson, M.A., Peraza Lope, C., Eds.; The University of Colorado Press: Boulder, CO, USA, 2014; pp. 149-192.

26. Smith, M.E. The archaeological study of neighborhoods and districts in ancient cities. J. Anthropol. Archaeol. 2010, 29, 137-154.

27. Masson, M.A.; Hare, T.S.; Peraza Lope, C. The social mosaic. In Kukulkan's Realm: Urban Life at Ancient Mayapán; Masson, M.A., Peraza Lope, C., Eds.; The University of Colorado Press: Boulder, CO, USA, 2014; pp. 193-268.

28. Tourtellot, G. III Excavations at Seibal, Department of Peten, Guatemala: Peripheral Survey and Excavation, Settlement and Community Patterns; Peabody Museum of Archaeology: Cambridge, MA, US, 1988; p. 16.

29. Freidel, D.A.; Sabloff, J.A. Cozumel: Late Maya Settlement Patterns; Academic Press: New York, NY, USA, 1984.

30. Chase, A.F.; Chase, D.Z. Ancient Maya causeways and site organization at Caracol, Belize. Anc. Mesoam. 2001, 12, 273-281.

31. Chase, D.Z.; Chase, A.F. Archaeological perspectives on Classic Maya social organization from Caracol, Belize. Anc. Mesoam. 2004, 15, 139-147.

32. Ruppert, K.; Smith, A.L. Excavations in House Mounds at Mayapan. Excavations in House Mounds at Mayapan; The Carnegie Institute of Washington: Washington, DC, USA, 1957.

33. Garza, T.; de González, S.; Kurjack Bacso, E.B. Atlas Arqueológico del Estado de Yucatán; Instituto Nacional de Antropología e Historia: Merida, México, 1980; Volume 1.

34. Dunning, N.P. Down on the farm: Classic Maya homesteads as farmsteads. In Ancient Maya; Commoners, J., Lohse, F., Valdez, Jr., Eds.; University of Texas Press: Austin, TX, USA, 2004; pp. 97-116.

(C) 2014 by Timothy S. Hare, Marilyn A. Masson, and Bradley W. Russell; licensee MDPI, Basel, Switzerland. This article is an open access article distributed under the terms and conditions of the Creative Commons Attribution license (http://creativecommons.org/licenses/by/3.0/). 